\title{
Permissive Linker Insertion Sites in the Outer Membrane Protein of 987P Fimbriae of Escherichia coli
}

\author{
DIETER M. SCHIFFERLI* AND MICHAEL A. ALRUTZ \\ Department of Pathobiology, University of Pennsylvania School of Veterinary Medicine, \\ Philadelphia, Pennsylvania 19104
}

Received 17 May 1993/Accepted 11 December 1993

\begin{abstract}
The FasD protein is essential for the biogenesis of 987P fimbriae of Escherichia coli. In this study, subcellular fractionation was used to demonstrate that FasD is an outer membrane protein. In addition, the accessibility of FasD to proteases established the presence of surface-exposed FasD domains on both sides of the outer membrane. The fas $D$ gene was sequenced, and the deduced amino acid sequence was shown to share homologous domains with a family of outer membrane proteins from various fimbrial systems. Similar to porins, fimbrial outer membrane proteins are relatively polar, lack typical hydrophobic membrane-spanning domains, and possess secondary structures predicted to be rich in turns and amphipathic $\beta$-sheets. On the basis of the experimental data and structural predictions, FasD is postulated to consist essentially of surface-exposed turns and loops and membrane-spanning interacting amphipathic $\beta$-strands. In an attempt to test this prediction, the $f a s D$ gene was submitted to random in-frame linker insertion mutagenesis. Preliminary experiments demonstrated that it was possible to produce $f a s D$ mutants, whose products remain functional for fimbrial export and assembly. Subsequently, 11 fas $D$ alleles, containing linker inserts encoding $\beta$-turninducing residues, were shown to express functional proteins. The insertion sites were designated permissive sites. The inserts used are expected to be least detrimental to the function of FasD when they are inserted into surface-exposed domains not directly involved in fimbrial export. In contrast, FasD is not expected to accommodate such residues in its amphipathic $\beta$-strands without being destabilized in the membrane and losing function. All permissive sites were sequenced and shown to be located in or one residue away from predicted turns. In contrast, 5 of 10 sequenced nonpermissive sites were mapped to predicted amphipathic $\beta$-strands. These results are consistent with the structural predictions for FasD.
\end{abstract}

Many gram-negative bacteria express adhesive fimbriae (39). These organelles consist of helical arrangements of protein subunits $(4,13)$. Fimbrial biogenesis on the bacterial surface requires subunit export across two membrane barriers. Typically, genes encoding the proteins required for fimbrial biogenesis are clustered together with fimbrial structural genes on a single replicon. Many of the accessory proteins have aminoterminal export signal sequences which are cleaved off by a host- or fimbrial type-specific signal peptidase $(25,46)$, indicating that they cross the cytoplasmic membrane. Moreover, since the export of the well-studied type 1 fimbriae has been shown to require SecA (10), it is commonly assumed that all fimbria-specific proteins which translocate through the cytoplasmic membrane utilize host components of the general export system (46).

After crossing the cytoplasmic membrane of Escherichia coli, the fimbria-specific accessory proteins form a second transport system translocating fimbrial subunits across the outer membrane (9). Genetic studies have indicated that 987P fimbriation and adhesion of porcine enterotoxigenic $E$. coli require the expression of eight genes, six of them, fas $B$ to fas $G$, encoding such accessory proteins $(9,48)$. As with other fimbrial types, some accessory proteins of the 987P system may be incorporated in the fimbrial structure, along with the 987P FasA subunit, as minor components (49). All studied fimbrial systems express at least two proteins which are exclusively involved in export functions. The 987P counterparts of these

\footnotetext{
* Corresponding author. Mailing address: Department of Pathobiology, University of Pennsylvania School of Veterinary Medicine, 3800 Spruce St., Philadelphia, PA 19104-6049. Phone: (215) 898-1695. Fax: (215) 898-9923.
}

proteins are FasB and FasD. Functional and structural data on FasB indicate that this protein is a periplasmic chaperone for 987P fimbrial subunits $(46 \mathrm{a}, 48)$. Fimbrial systems characteristically have one chaperone protein associating with fimbrial subunits in the periplasm, protecting them from proteolytic degradation and preventing them from assembling or aggregating prematurely in the wrong subcellular compartment $(9$, $18,30)$. This is consistent with previous studies which showed that certain fimbrial subunits, 987P subunits included, have the capacity to associate spontaneously into fimbria-like structures in vitro in the absence of other proteins $(1,47)$.

How fimbrial subunits cross the outer membrane to form the fimbrial thread on the bacterial surface remains to be elucidated. Currently, it is known that each fimbrial gene cluster encodes a single 80 - to $100-\mathrm{kDa}$ protein that is required for fimbrial export. This protein is characteristically the largest and the only one of every studied fimbrial system which is stably associated with the outer membrane (9). A recent study with the Pap fimbriae has shown that the various subunits of the fimbriae bind with different affinities to the outer membrane protein (OMP) PapC (11). The respective affinities corresponded to the subunit ordering in the fimbrial structure, the subunit with the highest affinity being the first or tip subunit of the fimbriae. Therefore, PapC was proposed to play an active role in determining the correct order of subunit assembly. As such, PapC was designated a molecular usher $(11,22)$.

For the 987P fimbrial system, FasD was previously identified as the PapC analog since it was the largest protein of this system $(48,49)$. In this article, FasD exposure on the bacterial surface is established, confirming that it is an OMP. Its primary structure was determined and was shown to exhibit a significant level of homology with the sequences of the largest 


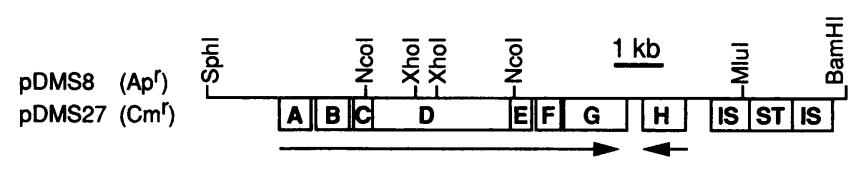

pDMS167 (Apr)

pDMS159 $\left(\mathrm{Cm}^{\mathrm{r}}\right)$

pDMS13 (Ap $\left.{ }^{r}\right)$

pDMS165 (Cm')

FIG. 1. Physical map of the cloned 12-kb 987P fimbrial gene cluster contained in pDMS8 (pBR322 derivative) or pDMS27 (pACYC184 derivative) and of additional plasmid constructs. The coding region for the eight fas genes and the location of the transposon encoding a heat-stable enterotoxin are indicated by boxes. The arrows indicate the directions of transcription of the fas genes.

proteins of many other fimbrial systems. This homology suggests the existence of conformational constraints on the structure of FasD and other fimbrial OMPs required for their pivotal role in fimbrial biogenesis. In an attempt to distinguish FasD domains which are required for fimbrial export from less essential sites, the mutagenic approach presented and discussed in this article was carried out.

(Fart of this work was presented at the 93rd General Meeting of the American Society for Microbiology, Atlanta, Ga., 16 to 20 May 1993.)

\section{MATERIALS AND METHODS}

Bacterial strains, media, and reagents. E. coli MH6085 (dcm-6 dam-3 metB galK galT lacY tsx thi ton $m$ tl?; kind gift from M. Howe), was used to test for ApaI linker insertions. Strain CC118 (31) was utilized for detecting and producing FasD-PhoA fusion products. For the immunodetection of FasD, host strain DMS902, a phoA recA derivative of nonfimbriated strain MC4100, was used. This strain was constructed by $\mathbf{P 1}$ transduction (32) in two steps, preparing phage lysates in SM547 [MC1000 $\Delta$ (phoA-proC) phoR tsx::Tn5; kind gift from C. Manoil] and RT628 (JF626 recA1 srl::Tn10; kind gift from R. Taylor). Nonfimbriated host strain SE5000 (MC4100 recA56) (50) was used for all other studies. Cultures for colony isolations or plasmid purifications were grown in LB media (32) with appropriate antibiotics used at the following concentrations: ampicillin, $200 \mu \mathrm{g} / \mathrm{ml}$; chloramphenicol, $30 \mu \mathrm{g} / \mathrm{ml}$; kanamycin, $45 \mu \mathrm{g} / \mathrm{ml}$. Media components were purchased from Difco Laboratories (Detroit, Mich.), and, unless specified, reagents were purchased from Sigma Chemical Co. (St. Louis, Mo.). Restriction and modification enzymes and the SmaI linker were from New England BioLabs (Beverly, Mass.), the ApaI linker was from Pharmacia LKB Biotechnology (Piscataway, N.J.), and pancreatic DNase was from GIBCO-BRL (Gaithersburg, Md.). Unidirectional removal of DNA was accomplished with the exonuclease III-S1 nuclease kit from Promega (Madison, Wis.).

Plasmid constructs. All plasmid constructs (Fig. 1) originate from pDMS6 and pDMS8 (pBR322 derivatives) or pDMS27 (pACYC184 derivative) containing all of the fas genes required for 987P fimbrial expression and adhesion on a 12-kb SphI-BamHI DNA fragment $(48,49)$. For pDMS8 and pDMS27, the vectors carry T7 promoters upstream of fas $A$ to fas $G$, which can be used for specific gene expression as described previously (48). Standard procedures (45) were used to construct the following plasmids. A MluI-BamHI deletion of pDMS8 (pDMS167) helped to stabilize the plasmid by removing most of the transposon encoding a heat-stable enterotoxin (Fig. 1). This deletion did not affect fas gene expression as demonstrated by the fimbriated phenotype of SE5000 carrying pDMS167. Plasmid pDMS13 was derived from pDMS8 as an in-frame $X$ hoI deletion in fas $D$ (Fig. 1). Plasmid pDMS159 was derived from pDMS27 by deleting both its MluI-BamHI and $X$ hoI fragments as described above. A Klenow enzyme-treated $N c o$ I fragment from pDMS8 (Fig. 1) containing fas $D$ was inserted, in each orientation, into the EcoRV site of the polylinker engineered in the lac $Z$ gene of phagemid pKS and pSK (Stratagene, La Jolla, Calif.) to obtain pDMS137, pDMS138, pDMS148, and pDMS149. A vector with a T7 promoter and a chloramphenicol resistance gene was prepared by deleting the HindIII fragment of pDMS27 containing the fas genes (48). This vector was used to prepare pDMS165 by subcloning fas $D$ from pDMS148 (HindIII-XbaI fragment) downstream of the $\mathrm{T} 7$ promoter. The various fas $D$-pho $A$ fusions originate from a collection of TnphoA mutants of pDMS6 prepared in a previous study (48). The HindIII-XhoI fragment of Tnpho $A$ insertion 4.23 encoding the whole fusion product was subcloned into pKS downstream of the T7 promoter to make pDMS168.

Specific labeling of Fas proteins and subcellular fractionation. Fas proteins were specifically labeled for $10 \mathrm{~min}$ with a mixture of ${ }^{35} \mathrm{~S}$-methionine and ${ }^{35} \mathrm{~S}$-cysteine (NEN Research Products, Boston, Mass.) by using a T7 expression system as described previously $(48,53)$. Total protein samples were prepared by centrifuging $0.5 \mathrm{ml}$ of each bacterial culture and solubilizing the pellets in sodium dodecyl sulfate-polyacrylamide gel electrophoresis (SDS-PAGE) sample buffer. Outer membrane fractions were prepared from spheroplasts by standard techniques (2). Briefly, $10 \mathrm{ml}$ of labeled bacteria was centrifuged. Pelleted bacteria were resuspended in $90 \mu \mathrm{l}$ of 30 $\mathrm{mM}$ Tris- $\mathrm{HCl}(\mathrm{pH} \mathrm{8.0)-20 \%} \mathrm{sucrose} \mathrm{and} \mathrm{transferred} \mathrm{to} \mathrm{micro-}$ centrifuge tubes, and $10 \mu \mathrm{l}$ of lysozyme $(1 \mathrm{mg} / \mathrm{ml}$ in $0.1 \mathrm{M}$ EDTA) was added to each sample (40). After $30 \mathrm{~min}$ of incubation on ice, the obtained spheroplasts were stabilized with $\mathrm{MgCl}_{2}$ (20 $\mathrm{mM}$ final concentration) and centrifuged $(15,000 \times \mathrm{g}, 2 \mathrm{~min})$, and periplasmic proteins were removed with the supernatant. The spheroplasts were resuspended in $100 \mu \mathrm{l}$ of a $10 \mathrm{mM}$ Tris- $\mathrm{HCl}(\mathrm{pH} 8.0)-100 \mathrm{mM} \mathrm{NaCl}-10 \mathrm{mM}$ $\mathrm{MgCl}_{2}$ solution containing $1 \mu \mathrm{g}$ of DNase per $\mathrm{ml}$. The spheroplasts were lysed by sonicating twice for $1 \mathrm{~min}$ with a Cup Horn accessory at amplitude output 10 (model XL2020; Heat Systems, Farmingdale, N.Y.). To solubilize cytoplasmic membrane proteins, $N$-lauroylsarcosine, sodium salt (ICN Biochemicals, Cleveland, Ohio), was added to a final concentration of $0.5 \%$, and the samples were incubated for $20 \mathrm{~min}$ at room temperature. Intact cells were removed by centrifugation at $1,200 \times g$ for $10 \mathrm{~min}$ at $4^{\circ} \mathrm{C}$. Outer membranes were pelleted by high-speed centrifugation in a Beckman JA-18.1 rotor at $17,000 \mathrm{rpm}$ (tube angle, $25^{\circ}$ ) for $3.5 \mathrm{~h}$ in the cold. Pelleted outer membranes were resuspended in SDS-PAGE sample buffer. The quality of the enriched outer membrane fraction was evaluated by comparing the relative signals of labeled FasD with the ones of cytoplasmic chloramphenicol acetyltransferase and periplasmic $\beta$-lactamase encoded by the used plasmids (chloramphenicol acetyltransferase by pDMS27 and pDMS159 and $\beta$-lactamase by pDMS167).

To localize FasD-PhoA fusion proteins in the periplasm of bacteria grown to the stationary phase, the spheroplasting technique of Witholt et al. was used (57). Briefly, $3 \mathrm{ml}$ of overnight cultures was centrifuged, and pelleted bacteria were resuspended in $50 \mu \mathrm{l}$ of $200 \mathrm{mM}$ Tris- $\mathrm{HCl}(\mathrm{pH} \mathrm{8.0)}$. The 
following timed additions were made on ice: at $1 \mathrm{~min}, 1 \mu \mathrm{l}$ of $0.05 \mathrm{mM}$ EDTA; at $2 \mathrm{~min}, 50 \mu \mathrm{l}$ of $200 \mathrm{mM}$ Tris- $\mathrm{HCl}(\mathrm{pH} 8)-1$ $M$ sucrose; at $3.5 \mathrm{~min}, 1 \mu \mathrm{l}$ of a $6-\mathrm{mg} / \mathrm{ml}$ concentration of lysozyme; at $4 \mathrm{~min}, 100 \mu$ l of cold deionized water; at $34 \mathrm{~min}$, $2 \mu \mathrm{l}$ of $1 \mathrm{M} \mathrm{MgCl}_{2}$. Further steps used to collect periplasmic fractions and isolate outer membranes are described above.

Anti-FasD antibodies. To prepare FasD antigen, the FasDPhoA fusion protein encoded by pDMS168 was produced in an expression system (53). Since this fusion product was shown to remain soluble in the periplasm, it could be isolated by affinity chromatography as described below. Briefly, strain CC118 (phoA) was transformed with pDMS168 and pGP1-2, grown to the late log phase $\left(A_{600}=1.5\right)$, activated for $30 \mathrm{~min}$ at $42^{\circ} \mathrm{C}$, and grown for an additional $90 \mathrm{~min}$ (53). The periplasmic fraction was isolated as described above (40), supplemented with $0.02 \%$ azide and a cocktail of protease inhibitors $(0.1 \mathrm{mM}$ phenylmethylsulfonyl fluoride, $0.1 \mathrm{mM}$ sodium metabisulfite, 2 $\mu \mathrm{g}$ of aprotinin per $\mathrm{ml}, 1 \mathrm{mg}$ of leupeptin per $\mathrm{ml}, 1 \mathrm{mg}$ of pepstatin per $\mathrm{ml}$ ), and dialyzed overnight at $4^{\circ} \mathrm{C}$ in phosphatebuffered saline (PBS)-0.1 M EDTA-0.02\% azide- $0.1 \mathrm{mM}$ phenylmethylsulfonyl fluoride- $0.1 \mathrm{mM}$ sodium metabisulfite. The periplasmic fraction was concentrated by ultrafiltration, and the fusion protein was purified by affinity chromatography on an antibacterial alkaline phosphatase antibody column (5 Prime $\rightarrow 3$ Prime, Inc., Boulder, Colo.) by conventional procedures (1 to $2 \mathrm{mg}$ protein per liter of culture). Purity was assessed to be $>95 \%$ by SDS-PAGE and Coomassie blue staining. Rabbits were immunized as described previously. Enzyme-linked immunosorbent assay titers of $\geq 1 / 200,000$ were reached. Before use, the antibodies were adsorbed with cell lysates of appropriate $E$. coli strains to remove nonspecific antibodies. Moreover, when produced in a malE strain, only FasD antigen was detectable by Western blot (immunoblot) analysis.

Protease accessibility to surface-exposed residues of FasD. Intact bacteria and spheroplasts, prepared as described above (40), were submitted to protease treatments. Strain DMS902 with plasmid pDMS165 was grown overnight. Aliquots of 0.5 $\mathrm{ml}$ of bacteria were spun, pelleted bacteria were resuspended in $0.1 \mathrm{ml}$ of appropriate buffer, and treated for $30 \mathrm{~min}$ at $37^{\circ} \mathrm{C}$ with either one of three proteases as follows: proteinase $\mathrm{K}$ $(11.4 \mathrm{U} / \mathrm{mg})$ at $5 \mathrm{mg} / \mathrm{ml}$ in PBS; trypsin $(9,800 \mathrm{~N} \alpha$-benzoyl-Larginine ethyl ester units $/ \mathrm{mg}$ ) at $0.5 \mathrm{mg} / \mathrm{ml}$ in $50 \mathrm{mM}$ $\mathrm{NH}_{4} \mathrm{HCO}_{3}$ (pH 7.8); Staphylococcus aureus V8 protease (650 $\mathrm{U} / \mathrm{mg}$; Promega) at $0.5 \mathrm{mg} / \mathrm{ml}$ in $50 \mathrm{mM} \mathrm{NH} \mathrm{HCO}_{3}$ (pH 7.8) for glutamic acid cleavage or at $0.5 \mathrm{mg} / \mathrm{ml}$ in $50 \mathrm{mM} \mathrm{NaPO}$ (pH 7.8) for aspartic and glutamic acid cleavage (17). Reactions were stopped by adding phenylmethylsulfonyl fluoride and $2 \times$ sample buffer and by immediately heat treating the samples $\left(100^{\circ} \mathrm{C}, 10 \mathrm{~min}\right)$.

SDS-PAGE and immunoblotting. Protein profiles of wholecell extracts or of subcellular fractions boiled in sample buffer were determined by SDS-PAGE as described previously (48). Radiolabeled samples were analyzed by fluorography. FasDPhoA fusion products were analyzed on Western blots by using anti-alkaline phosphatase and peroxidase-conjugated secondary antibodies as described previously (48). Blots were developed by using 3,3'-diaminobenzidine. FasD antigen was detected by Western blotting by using enhanced chemiluminescence (Amersham Corp., Arlington Heights, Ill.). Bacteria replica plated onto nitrocellulose were exposed to chloroform vapor for $15 \mathrm{~min}$ and to a lysis buffer $(100 \mathrm{mM}$ Tris- $\mathrm{HCl}[\mathrm{pH}$ 7.8], $150 \mathrm{mM} \mathrm{NaCl}, 5 \mathrm{mM} \mathrm{MgCl}{ }_{2}, 1.5 \%$ bovine serum albumin (BSA), $1 \mu \mathrm{g}$ of DNase I per $\mathrm{ml}$, and $40 \mu \mathrm{g}$ of lysozyme per $\mathrm{ml}$ ) for 12 to $16 \mathrm{~h}$ and rinsed twice with TNT $(10 \mathrm{mM}$ Tris- $\mathrm{HCl}[\mathrm{pH}$ 8.0], $150 \mathrm{mM} \mathrm{NaCl}, 0.05 \%$ Tween 20 ) as described elsewhere
(45). Rinsed blots were processed for antigen detection by using quaternary structure-specific anti-987P monoclonal antibody E11 (47), peroxidase-conjugated secondary antibodies, and 3,3'-diaminobenzidine as described above.

Seroagglutination. Slide agglutinations were performed with preadsorbed rabbit anti-987P fimbrial antiserum as described previously $(47,49)$.

DNA sequencing. Collections of subclones of plasmids pDMS137, pDMS138, pDMS148, and pDMS149 were constructed by using the unique restriction sites of the vectors for unidirectional deletions with exonuclease III and S1 nuclease (45). For some constructions, restriction sites in fas $D$ were used. Double-stranded plasmid DNA was sequenced by the chain termination method (45) with an Applied Biosystems model $373 \mathrm{~A}$ sequencer with forward or reverse lac $Z$ primers. The fas $D$ sequence of both strands was determined. Primers spaced approximately 200 bp over the entire length of $f a s D$ were prepared with an Applied Biosystems model 380B oligonucleotide synthesizer and used to sequence the linker insertion sites in fasD.

Homology analysis and structural predictions. The NBRFPIR Release 35 and the Swiss-Prot Release 24 protein data banks were searched for homologies to FasD, and all homologous proteins were aligned together with the CLUSTAL algorithm (15a) from DNASTAR (Madison, Wis.). The method presented by F. Jähnig to study OMPs was used to predict the structure of FasD (19).

Linker insertion mutagenesis. $\mathrm{CsCl}$ pDMS165 DNA was prepared by conventional techniques $(45,51)$ after plasmid amplification by the addition of $50 \mu \mathrm{g}$ of spectinomycin per $\mathrm{ml}$ at the early to mid-log phase of growth (optical density at 600 $\mathrm{nm}, 0.4)$. First, four unique blunt end restriction sites in fas $D$ (PvuII, StuI, EcoRV, and SnaBI) were used to insert a phosphorylated 12-mer SmaI linker (TCCCCCGGGGGA) by conventional techniques (45). Second, linkers were inserted randomly into fas $D$. For this, a random population of circularly permuted molecules was obtained by digesting pDMS165 with limiting concentrations of pancreatic DNase $I$ in a mixture of $50 \mathrm{mM}$ Tris (pH 7.6), $10 \mathrm{mM} \mathrm{MnCl}$, and $50 \mu \mathrm{g}$ of BSA per ml $(14,45)$. Because under even optimized conditions, no more than a third of target plasmid linearizes, plasmid cut only once was isolated by agarose gel electrophoresis by using lowmelting-agarose and $\beta$-agarase I (New England Biolabs). The DNA ends were blunted with Klenow fragment of DNA polymerase I (45). A molar excess of 40 to 400 phosphorylated 6-mer ApaI linkers (GGGCCC) was added to linear pDMS165 before ligation with T4 DNA ligase (45). In later experiments, linear DNA was pretreated with shrimp alkaline phosphatase (United States Biochemicals, Cleveland, Ohio) to prevent self ligation. DNA was used to transform competent MH6085 cells by electroporation (12). An additional linearization step was performed to enrich for linker insertions and to remove multiply inserted linkers. For this, approximately 10,000 transformants were pooled and grown to the stationary phase, and plasmid DNA was isolated as described above. The DNA was restricted with ApaI, and linear DNA was isolated, ligated, and used to transform MH6085 or SE5000 pDMS13 as described above. Transformants were analyzed by one of two techniques. In the first approach, plasmid minipreps of transformants were analyzed by restriction mapping to determine linker insertion sites in pDMS165. Plasmids with linker inserted in fas $D$ were used to transform SE5000 pDMS13 and tested for fimbriation by seroagglutination. With the second approach, distinct colonies of transformed SE5000 pDMS13 were used to inoculate LB broth in microtiter wells (15\% glycerol was added to the media for long-term storage at $\left.-70^{\circ} \mathrm{C}\right)$. Bacteria were replica 


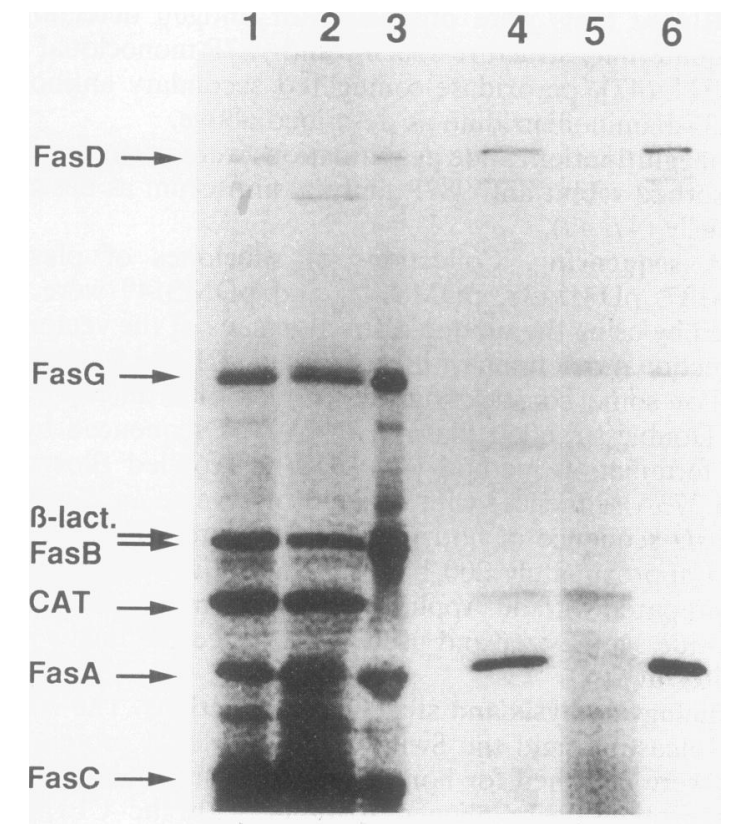

FIG. 2. Proteins labeled in E. coli SE5000 after activation of T7 transcription, separated by SDS-PAGE, and analyzed by fluorography. The results with total bacterial extracts (lanes 1 to 3 ) and outer membrane fractions (lanes 4 to 6) of SE5000 containing pDMS27 (fas $D^{+}$; lanes 1 and 4), pDMS159 (fas D; lanes 2 and 5), or pDMS167 $\left(\right.$ fas $D^{+}$; lanes 3 and 6 ) are shown. Plasmids pDMS27 and pDMS159 express chloramphenicol acetyltransferase (CAT), and pDMS167 expresses $\beta$-lactamase ( $\beta$-lact.).

plated from the wells to nitrocellulose circles placed on LB agar plates containing ampicillin and chloramphenicol. Bacteria grown on the nitrocellulose circles were analyzed by the immunoblot procedure described above. To identify and map linker insertions, plasmids of positive isolates were studied by restriction analysis after growing bacteria in LB broth with chloramphenicol alone. Plasmid pDMS13 was diluted out by omitting ampicillin from the medium.

Nucleotide sequence accession number. The nucleotide sequence of $f a s D$ has been deposited in the GenBank data base and given the accession number L22659.

\section{RESULTS}

Subcellular localization of FasD. The results of a previous study using protein fusion technology suggested that FasD crosses the cytoplasmic membrane (48). By analogy to other fimbrial systems, but on the sole basis of the size of FasD and its requirement for fimbriation, the protein was proposed to home to the outer membrane (48). In this study, a biochemical approach has been taken to determine directly where FasD localizes. SDS-PAGE and fluorography of E. coli SE5000 with plasmids pDMS27 and pDMS167 synthesizing all the Fas proteins indicated that FasD localizes to the outer membrane (Fig. 2, lanes 4 and 6). The data show that the isolated outer membrane fraction was not contaminated by periplasmic $\beta$-lactamase and only slightly by the cytoplasmic CAT. In a fas $D$ in-frame deletion mutant [SE5000(pDMS159)], the internally truncated FasD protein could not be detected in the outer membrane (Fig. 2, lane 5). The most prominent Fas protein in the outer membrane was the fimbrial subunit FasA. In the fas $D$ mutant, FasA, which was absent from the outer membrane

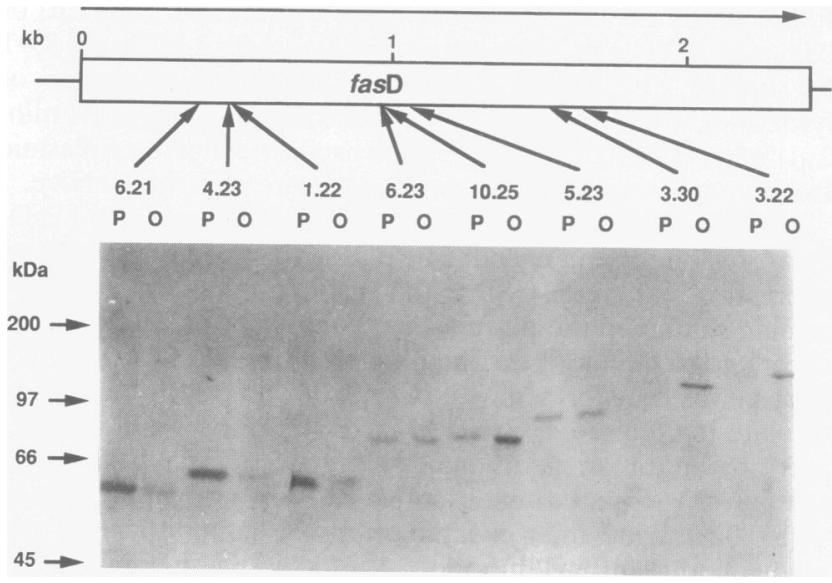

FIG. 3. Physical map and Western blot of TnphoA inserts in the fas $D$ gene of pDMS6. Hybrid proteins isolated with periplasmic $(\mathrm{P})$ or outer membrane $(\mathrm{O})$ fractions were visualized with anti-alkaline phosphatase antibodies. The corresponding mutations are indicated at the top of each pair of lanes labeled $\mathrm{P}$ and $\mathrm{O}$, and the locations of the in-frame fusion joints between fasD and phoA are indicated on the map by arrows. The direction of transcription of fasD is indicated by an arrow above the map. Molecular masses of standard proteins, given in kilodaltons, are indicated at the left.

(Fig. 2, lane 5), accumulated in the periplasm (data not shown). This suggests that membrane-associated FasD is required for FasA uptake by the outer membrane. Although some of the additional minor bands may result from internal translation start sites in fas $D$, pulse-chase experiments suggested that most of them are due to proteolysis (data not shown). For example, a minor protein migrating between FasD and FasG $\left(M_{\mathrm{r}}=68,000\right.$; data not shown) became the major outer membrane band after pulse-chase labeling. Similar findings have been described for PapC and the CS3 fimbrial OMP $(11,20,38)$. FasD has three potential OmpT cleavage sites; the accessibility of any one of two of them (between residues 730 and 731 or 757 and 758 ) to this outer membrane protease could explain the described band (52). PapC and CS3 have eight and nine, respectively, potential OmpT cleavage sites, which may explain the common findings. The truncation of fimbrial OMPs may have no physiological relevance since all of the studies used multicopy-number plasmids with expression systems or minicells. In any case, our data support previous genetic studies, which suggested that FasD is the 987P OMP.

Subcellular localization of FasD-PhoA fusion products. To confirm the localization of FasD in the outer membrane of $E$. coli, differential compartmentalization of several previously described active FasD fusions to alkaline phosphatase was investigated (48). Periplasmic and outer membrane fractions of host strain $\mathrm{CC} 118$ (phoA) containing pDMS6 plasmid derivatives with Tnpho $A$ inserted in different areas of fas $D$ were studied by Western blot analysis using anti-PhoA antibodies. As shown in Fig. 3, the subcellular localization of FasD-PhoA fusions indicated that fusion products which contained at least three-fifths of the FasD sequence were isolated only in outer membrane fractions (mutants 3.30 and 3.22). FasD-PhoA fusion proteins remained in the periplasm when they contained only the $\mathrm{NH}_{2}$-terminal fifth of FasD (mutants $6.21,4.23$, and 1.22). Fusion products of intermediate sizes were isolated in both fractions (mutants 6.23, 10.25, and 5.23). These results suggest that parts of FasD can direct a periplasmic protein to the outer membrane. Although it is not known 


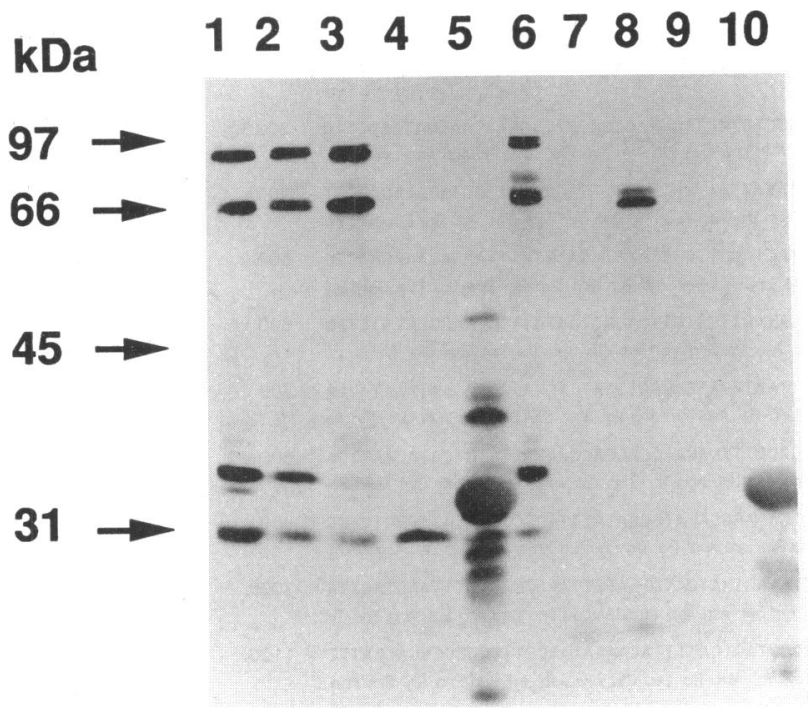

FIG. 4. Western blot of total proteins of E. coli SE5000 (pDMS165) probed with anti-FasD antibody and analyzed by enhanced chemiluminescence. Lanes: 1 to 5 , intact bacteria; 6 to 10 , spheroplasts; 1 and 6 , control without proteases; 2 and 7 , trypsintreated bacteria; 3 and 8 , bacteria treated with V8 protease used under conditions for cleavage at Glu residues; 4 and 9, bacteria treated with V8 protease used under conditions for cleavage at Asp and Glu residues; 5 and 10 , proteinase $\mathrm{K}$-treated bacteria.

whether the folding and insertion of the remaining portion of FasD is the same as those for its native state, our results are at least consistent with the localization studies of native FasD.

Surface exposure of FasD. The potential accessibility of surface-exposed domains of FasD to proteases was determined. The obtained anti-FasD antibody was utilized to identify FasD by Western blot and enhanced chemiluminescence. The antibody recognized FasD and some of its degradation products, which were described above (Fig. 4). Moreover, in addition to submitting intact bacteria to protease treatments, prepared spheroplasts were treated in a similar fashion to identify FasD domains which are exposed on the periplasmic surface of the outer membrane. Trypsin and V8 protease, used under specific conditions for glutamic acid residues, did not affect FasD in intact bacteria (Fig. 4). In contrast, the broadrange protease proteinase $\mathrm{K}$ and $\mathrm{V} 8$ protease, used under conditions cleaving both aspartic and glutamic acid residues, were able to degrade portions of FasD. Taken together, these data indicate that a portion of FasD is surface exposed and that at least one of its domains includes an aspartic acid residue which is accessible to V8 protease. Interestingly, FasD of spheroplasts was susceptible to all proteases, suggesting that larger domains of FasD are exposed on the periplasmic side of the outer membrane.

DNA sequence of $f a s D$. The DNA sequence of the NcoI fragment of pDMS8 and the deduced primary structure of FasD are shown in Fig. 5. Initiation of translation of fasD is proposed to involve a typical ribosomal binding site (Fig. 5, underlined). The proposed translational start site of fas D (Fig. 5) was confirmed by in vivo transcription and translation of two deletion constructs with the T7 expression system (data not shown). The extent of the deletions, which were obtained by exonuclease III treatments, were determined by DNA sequencing. FasD was still expressed after the first 164 bp shown in Fig. 5 were deleted. In contrast, FasD was not detected when the first $222 \mathrm{bp}( \pm 3 \mathrm{bp})$ were deleted. However, additional bands of lower molecular weights (distinct from the protein band with an $M_{\mathrm{r}}$ of 68,000 mentioned above) were visible, confirming the existence of at least one internal translation start site in fas $D$. A cleavage site for a typical leader sequence of exported proteins in E. coli (54) is proposed (Fig. 5, arrow). The calculated molecular mass of the exported FasD $\left(M_{\mathrm{r}}=\right.$ $92,366)$ corresponds to that previously calculated for FasD by SDS-PAGE (48). The two most frequently occurring amino acid residues are serines and glycines, accounting for $22 \%$ of all residues. FasD has only two cysteines. FasD is hydrophilic and has no apparent hydrophobic transmembrane segment, with the exception of the one contained in the signal sequence. These characteristics are consistent with OMPs (36). The calculated $\mathrm{pI}$ is 7.36 .

FasD belongs to a new family of OMPs. All of the first proteins aligning to FasD in a homology search of protein data banks were fimbrial proteins of similar size in E. coli, Klebsiella pneumoniae, Salmonella typhimurium, Yersinia pestis, and Bordetella pertussis $(3,20,24,27,34,38,42,43,56)$. Several of these proteins have been shown to be OMPs. No other OMPs were included in the next 20 listed proteins of the search. These fimbrial proteins were aligned by penalizing gaps only slightly to better visualize domain alignments. By using the PAM100 residue weight table, the percent similarity varied between 19.2 and 32.7. Homologies were the strongest in the second fifth (Fig. 6) of the multiple alignment. The profiles of residue identities among at least six fimbrial OMPs are shown in Fig. 7A. Some residues are fully conserved among all 10 proteins. Glycine, tryptophan, tyrosine, and proline residues are preferentially conserved over other residues. Residues 302 to 310 in FasD (VPPGPFXIXD) correspond to the bestconserved span of residues among these proteins. All of the fimbrial OMPs have two cysteines aligning at the carboxyterminal end and, with the exception of FasD, two cysteines aligning around residues 90 and 110. This suggests that the aligning pairs of cysteines make disulfide bridges on either side of the membrane. The similarity in function and structure of these proteins indicates that they should be classified as a new family of OMPs in gram-negative bacteria. Moreover, these proteins can be differentiated from type IV fimbrial OMPs since they share neither homologous sequences nor the consensus sequence of lipoprotein processing sites found with type IV fimbrial OMPs (41).

Structure predictions for FasD. On the basis of two extensively studied groups of OMPs, the porins (including OmpA and LamB) and the active transporters of iron siderophores and vitamin $B_{12}(25,36,44)$, OMPs are proposed to be relatively hydrophilic proteins which span the outer membrane as $\beta$-strands, in contrast to the hydrophobic $\alpha$-helical structures of bacterial and eucaryotic cytoplasmic membrane proteins $(23,37,44)$. Recently resolved crystal structures of the Rhodobacter capsulatus and E. coli OmpF and PhoE porins indicated that each subunit of these trimers consists of 16 $\beta$-strands forming an antiparallel $\beta$-barrel $(8,55)$. Combinations of certain algorithms, used to identify turns and hydrophobic and amphipathic domains, have been surprisingly correct in predicting most of the membrane-spanning domains of porins $(19,21,50)$ and are being used to support structural studies on siderophore receptors (28). Applying Jähnig's predictors, FasD consists mainly of amphipathic $\beta$-strands, $\beta$-turns, and loops (Fig. 7). Other fimbrial OMPs demonstrate essentially similar predicted structures. Moreover, the size of fimbrial OMPs and the number of predicted $\beta$-amphipathic strands are similar to the ones described or proposed for siderophore receptors (28). This suggests a working model in 
CCATGgGTATAATATATTTAAATGAGgGTGAAgTATTTGACAAAAAAAGAAAATATTATTTGTCGgTTAGTTTCATCCCCAAAAAAAAAGATTCTGATGA

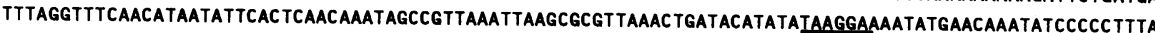
Met Aso Lys Tyr Pro Pro Lou TTAACAATGTTGATCATTGGTATTGGTTCCAATGCGGTTGCGgGGGCTATTTCGACCCCTCACTACTTGCAACCGATATTGGAAATAATGATAAGTTAG Lou Thr Met Lou lle lle Gly Ile Gly Ser Aen Ala Val Ala Gly Asp Tyr Pho Asp Pro Ser Lou Lou Ala Thr Asp lle Gly Aen Asen Asp Lys Lou

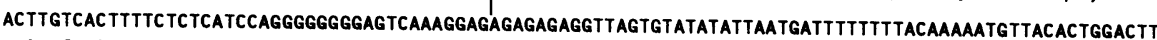
Asp Lou Ser Lou Pho Ser His Pro Gly Gly Gly kal Lys Gly Glu Arg Glu Kal Ser Val Tyr lle Aen Asp Pho Phe Tyr Lys Asn Val Thr Leu Asp Pho TGAAAATGGAATTTCCGgAGCCCTAGAGCCAATTTTTCCATCAGgGTTITTTGATAACATATTAGCTTCGCCATATAGAagTATTAAaGAGAAGAACTC Glu Asn Gly Ile Ser Gly Ala Lou Glu Pro lle Phe Pro Ser Gly Phe Phe Asp Asn lle Lou Ala Ser Pro Tyr Arg Ser lle Lys Glu Lys Glu Lou

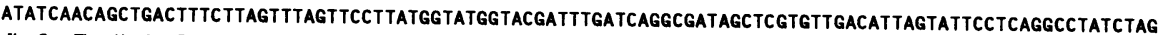
Ile Ser Thr Ala Asp phe Leu Ser Lou Kal Pro Tyr Gly Met Val Arg Pho Asp Gin Ala lle Ala Arg Val Asp lle Ser lle Pro Gin Ala Tyr Lou GGCGTGATGCTCAGATGAAATCAGCTCCTGAATCTTGGAATCAGGGTGTTCCTGCATTGTTAATAGATTACCGITTATCTGGAAGTAAAAATAAATATAA Gly Arg Asp Ala Gin Mot Lys Ser Ala Pro Glu Ser Trp Asn Gin Gly Val Pro Ala Lou Lou lle Asp Jyr Arg Lou Ser Gly Ser Lys Asen Lys Iyr Asn CTATGGTTCATCACAGAATTITTATGCTAACGCATTTITAGgTTTCAACTTAATGgGG TGGCGTTTGAGAACCACCACGAATTACATGTCGTACAATTCA Tyr Gly Ser Ser Gln Asn Phe Tyr Ala Asn Ala Phe Lou Gly Phe Asn Lou Met Gly Trp Arg Lou Arg Thr Thr Thr Asn Tyr Met Ser Tyr Asn Ser

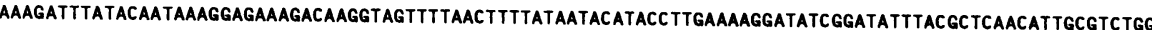
Lys Asp Lou Tyr Asn Lys Gly Glu Arg Gin Gly Ser Phe Asn Phe Tyr Asn Thr Tyr Lou Glu Lys Asp lle Gly Tyr Lou Arg Ser Thr Lou Arg Lou GgGAGCTATCAACTCGAGgGATGATTCTTGAATCATTTAATTTCAAAGGTGGAAAGATTTATAGTAATGATGAAATGTTAAATGACCGTTTACGTAGTTA Gly Glu Leu Ser Thr Arg Gly Met lle Leu Giu Ser Phe Asn Phe Lys Gly Gly Lys lle Tyr Ser Asn Asp Glu Met Leu Asn Asp Arg Leu Arg Ser Tyr TACTCCAACTGTAAGAGgTATAGCAAGTAGCCAGGCAGTGgTAACTATTAAGCAGgGgGgG TAGTCATTTTIACAAAAAAACGTTCCGCCCGGACCATIT Thr Pro Thr kal Arg Gly lle Ala Ser Ser Gin Ala kal Kal Thr lle Lys Gin Gly Gly kal Val lle Leu Gin Lys Asn Val Pro Pro Gly Pro Phe

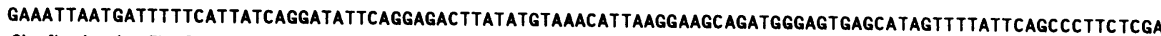
Glu lle Asn Asp Phe Ser Leu Ser Gly Tyr Ser Gly Asp Lou Tyr kal Asn lle Lys Glu Ala Asp Gly Ser Glu His Ser Phe lle Gin Pro Phe Ser

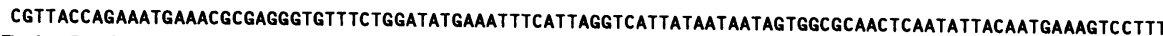
Thr Lou Pro Glu Met Lys Arg Giu Gly Val Ser Gly Tyr Glu Ile Ser Lou Gly His Tyr Asn Asn Ser Gly Ala Thr Gin Tyr Tyr Asn Glu Ser Pro Pho

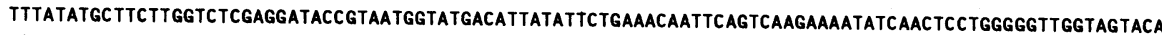
Leu Tyr Ala Ser Trp Ser Arg Gly Tyr Arg Asn Gly Met Thr Lou Tyr Ser Glu Thr lle Gin Ser Arg Lys Tyr Gin Lou Lou Gly Val Gly Ser Thr TTATCTCTTGGgGATTTTGGGGCTGTGTCTGGTGATGCATCATTGTCACGTGCAAATAAATATGACAAAATTCATTCAGGGCAATCTTACGGCTTAAAAT Lou Ser Lou Gly Asp Phe Gly Ala Val Ser Gly Asp Ala Ser Lou Ser Arg Ala Asn Lys Jyr Asp Lys lle His Ser Gly Gin Ser Tyr Gly Lou Lys

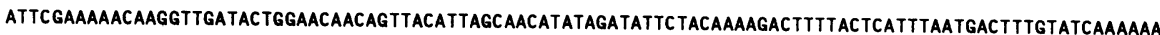
Tyr Ser Lys Asn Lys Val Asp Thr Gly Thr Thr kal Thr Lou Ala Thr Tyr Arg Tyr Ser Thr Lys Asp Phe Tyr Ser Phe Asn Asp Phe Val Ser Lys Asn TGACTCAGTTCAATATGTTTGGGATAACCGATTAAAAAATAGAATTACATTAAGTCTAAATCAATCTCTGGATGATTATGGTTCATTATCTTTAATCGCA Asp Ser Kal Gin Tyr Kal Trp Asp Asn Arg Lou Lys Asn Arg Ile Thr Lou Ser Lou Asn Gin Ser Lou Asp Asp Tyr Gly Ser Leu Ser Leu lle Ala TCCCAACAAAATTATTGgACGAgTGATTATGTTAGTCGTTCCTTTTCATTATCGCATAGTTTTGgATgGaATGATATATTITTTTCAACATCCTTTTCTT Ser Gln Gin Asn Tyr Trp Thr Ser Asp Tyr kal Ser Arg Ser Phe Ser Lou Ser His Ser Phe Gly Trp Asn Asp llo Phe Phe Ser Thr Ser Pho Ser

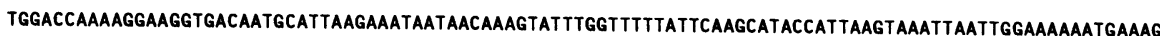
Lou Asp Gin Lys Glu Gly Asp Asn Ala Lou Arg Asn Asn Asn Lys Val Phe Gly Phe Tyr Ser Ser llo Pro Lou Ser Lys Lou lle Gly Lys Asn Glu Ser

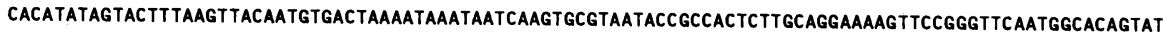
Thr Tyr Ser Thr Lou Ser Tyr Asn Val Thr Lys lle Asn Asn Gin kal Arg Asn Thr Ala Thr Lou Ala Gly Lys Val Pro Gly Ser Met Ala Gin Tyr

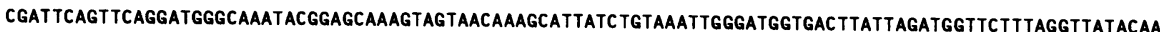
Arg Phe Ser Ser Gly Trp Ala Asn Thr Glu Gin Ser Ser Asn Lys Ala Leu Ser Val Asn Trp Asp Gly Asp Lou Leu Asp Gly Ser Lou Gly Tyr Thr GCTCCGgaAAAAATCGAATAACTGACTATAGCCTATCTGgCTCAGCAATTCTGTATCCTTGgCGACTAGCCATTGGGTCTGATAGTGTTATCAACGg TGC Ser Ser Gly Lys Asn Arg lle Thr Asp Tyr Ser Leu Ser Gly Ser Ala Ile Lou Tyr Pro Trp Arg Lou Ala lle Gly Ser Asp Ser Val lle Asn Gly Alo

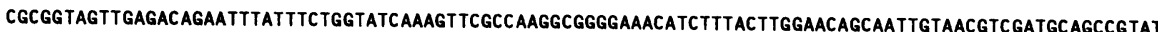
Ala Val Val Glu Thr Glu Phe lle Ser Gly lle Lys kal Arg Gin Gly Gly Glu Thr Ser Lou Lou Gly Thr Ala lle kal Thr Ser Met Gin Pro Tyr

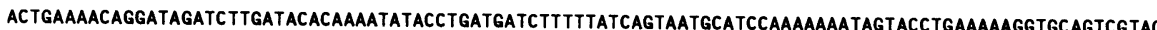
Thr Glu Asn Arg lle Asp Lou Asp Thr Gin Asn lle Pro Asp Asp Leu Pho lle Ser Asn Ala Ser Lys Lys lle kal Pro Glu Lys gly Ala Val Val CGgtTAAATACAATCTCTTTAAAgGTAagCAAAT TGTATTTAGTTTAAAACGTTATGATGgTACTCCATTGCCATTCGGATCTGTTGITTCTCTIGTGGG Pro kal Lys Tyr Asn Lou Phe Lys Gly Lys Gin lle kal Phe Ser Lou Lys Arg Tyr Asp Gly Thr Pro Lou Pro Pho Gly Ser Kal Kal Ser Lou Val Gly

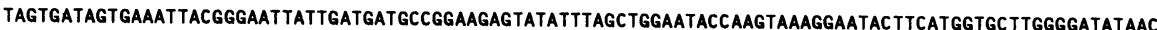
Ser Asp Ser Glu Ile Thr Gly lle lle Asp Asp Ala Gly Arg Val Tyr Lou Ala gly lle Pro Ser Lys Gly lle Lou His Gly Ala Trp Gly Tyr Asn AAGTCATGTGAGgTGTCTTTTAATCTTAACGgGAACCATCAAATAATTCAAATGAAATTATTGAATACGAAGGTGTATGTAAGTAATGAAATATTTATT Lys Sor Cys Glu Kal Ser Phe Asn Lou Asn Gly Lys Pro Ser Asn Asn Ser Asn Glu Ile lle Glu Tyr Glu Gly Val Cys Lys CACTATTCTACTAATATTTATATGTAAATATGGATATACGTTTGTTTCAAATCCATTACTATATCCATTTCCTAATGACACAAAGATAATTATTCATTCT 2800

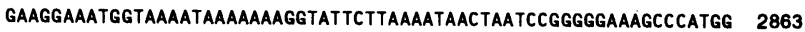

FIG. 5. Nucleotide sequence of the $N c o$ I fragment containing fas $D$ and deduced amino acid sequence of FasD. A ribosomal binding site (underlined) and a typical leader sequence cleavage site (arrow) are proposed.

which the membrane-spanning domains of FasD adopt a $\beta$-barrel structure, with joining surface-exposed $\beta$-turns or loops of various lengths.

Identification of permissive sites in FasD. FasD is the only 987P protein which fractionates exclusively with bacterial outer membranes. This suggests that FasD plays a central role in the translocation of fimbrial subunits through the outer membrane of $E$. coli. To better understand how FasD functions, a 


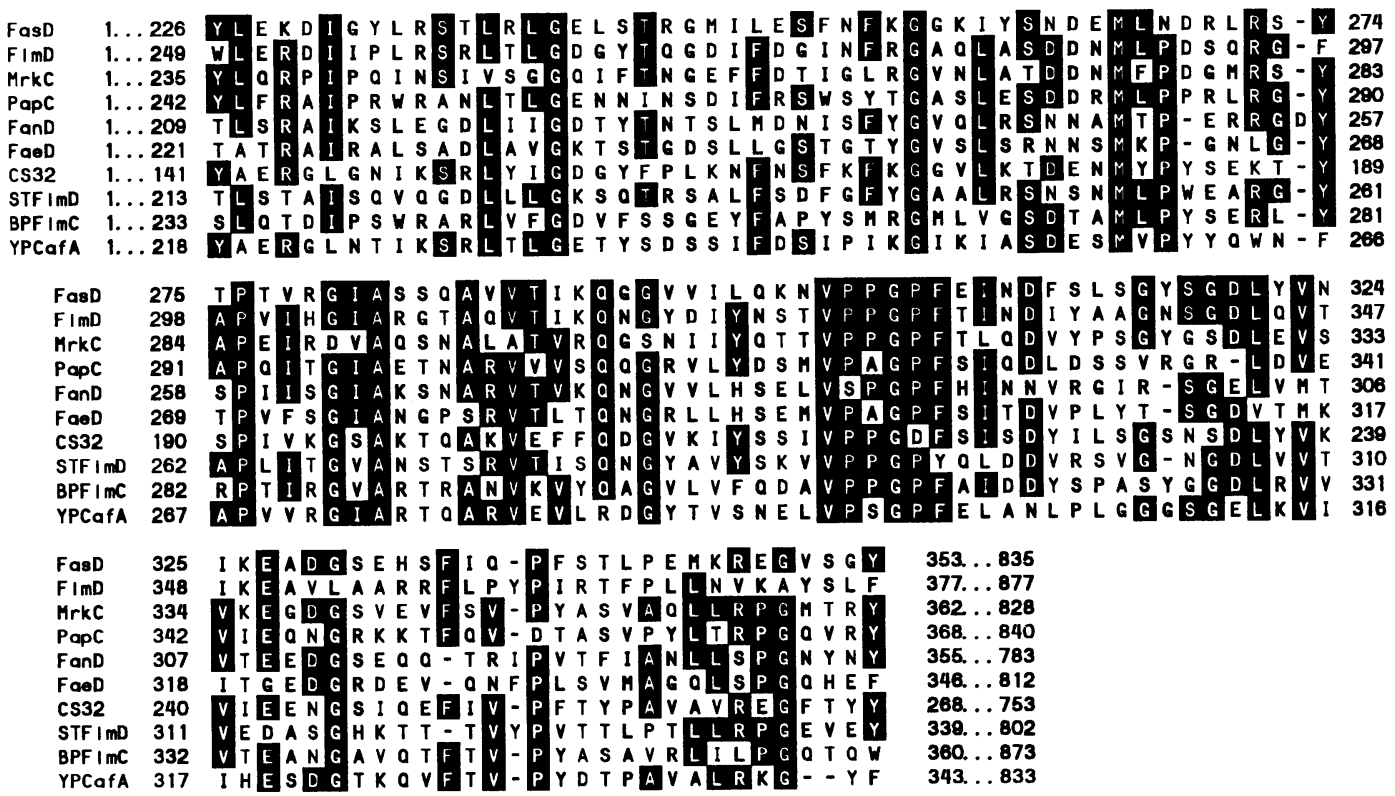

FIG. 6. Regions of FasD and nine additional fimbrial OMPs which gave the highest level of homologies when the CLUSTAL multiple alignment algorithm was used. FimD (27), PapC (38), FanD (43), FaeD (33), and CS32 (20) are E. coli proteins; MrkC is from K. pneumoniae (3); STFimD is from $S$. typhimurium (42); BPFimC is from B. pertussis (56); YPCafA is from Y. pestis (24). Amino acid residues are indicated on the left and right sides for each sequence.

brane. As presented above, our working model for FasD assumes that the membrane-spanning domains of this protein consist essentially of amphipathic $\beta$-sheets which stabilize the protein in the outer membrane. To optimize inactivation of the function of FasD after linker insertion into membrane-spanning $\beta$-sheets, we used linkers encoding residues acting as $\beta$-breakers, like proline and glycine. Therefore, the identification of nonpermissive sites should characterize most membrane-spanning domains and the surface-exposed domains which are involved in fimbrial export. In contrast, identified permissive sites should essentially represent connecting surface-exposed turns and loops (i.e., towards the periplasmic or bacterial surface) which are not involved in fimbrial export.

Preliminary experiments were used to determine whether it is possible to engineer in-frame mutations in fas $D$ (pDMS165) which can still complement a fasD mutant (pDMS13). For this, a $S m a \mathrm{I}$ linker was inserted in four unique restriction sites of fas $D$ with blunt ends (PvuII, StuI, EcoRV, and SnaBI). To identify a permissive site, complemented fas $D$ mutants were screened by seroagglutination with anti-987P fimbrial antibodies. From these constructs, only the insertion into EcoRV partially complemented a fasD strain (SE5000 with compatible plasmid pDMS13) for 987P fimbriation. Interestingly, this site is located in a predicted turn (Table 1 and Fig. 7), with a highly conserved proline absent only in FasD (Fig. 6, residue 268). In contrast, two of the three other inserts flank or reside in a predicted amphipathic $\beta$-strand. This result suggested that the proposed mutagenesis approach could be used on a larger scale to study FasD.

Accordingly, $A p a \mathrm{I}$ linkers were inserted randomly into pDMS165 previously cut with DNase I. Initially, plasmids from 235 independent colonies were isolated and $A p a \mathrm{I}$ insertions were mapped by restriction analysis. Plasmids with $A p a \mathrm{I}$ inserts in fas $D$ were tested by complementation analysis for fimbriation by using seroagglutination. Of 74 plasmids with inserts in fas $D$, six were complementing for fimbriation. The corresponding insertion sites were mapped and sequenced (Table 1 and Fig. 7; sites 249, 268, 362 twice, one with a short in-frame duplication of target DNA, 363, and 514). Seroagglutination was evaluated as described previously (49), and comparable strong reactions $(+++)$ were obtained when testing the wild type and four of the five mutated plasmids. Only the construct with an ApaI linker in site 268 complemented less efficiently, as shown by a weaker seroagglutination reaction $(+)$. In addition to simple linker insertions, several constructs demonstrated duplications or deletions of one or a few codons at the insertion site of the $A p a \mathrm{I}$ linker in the fas $D$ sequence. These changes probably resulted from using the Klenow fragment of $E$. coli DNA polymerase I to blunt protruding termini frequently created by DNase I (45).

To facilitate identification of permissive sites, an approach which eliminates unnecessary restriction mapping was used. For this, approximately 90 new colonies were first tested for fimbriation by immunoblotting, using monoclonal antibodies specific for the quaternary structure of $987 \mathrm{P}$ fimbriae. Four additional permissive sites were identified in fas $D$ by mapping and sequencing ApaI inserts in plasmids of colonies that were positive by immunoblot. That the corresponding FasD proteins were functional was confirmed by seroagglutination as described above (Table 1 and Fig. 7; sites 202, 243, 604, and 704).

The occurrence of codon duplications and deletions (substitutions included) among 6 of the $10 \mathrm{ApaI}$ insertion mutants encoding a functional FasD protein suggested that, because of the DNase protocol used, many of the mutants encoding a nonfunctional product contained frameshifts. This was confirmed by analyzing the sequence of approximately 20 different ApaI insertion sites mapped between nucleotides 600 and 1,200 of fas $D$ (by using the coordinates of Fig. 5). In addition to out-of-frame mutants, many mutants with deletions and duplications of large DNA fragments (40 bp and more) were detected. Therefore, to determine the location of nonpermis- 

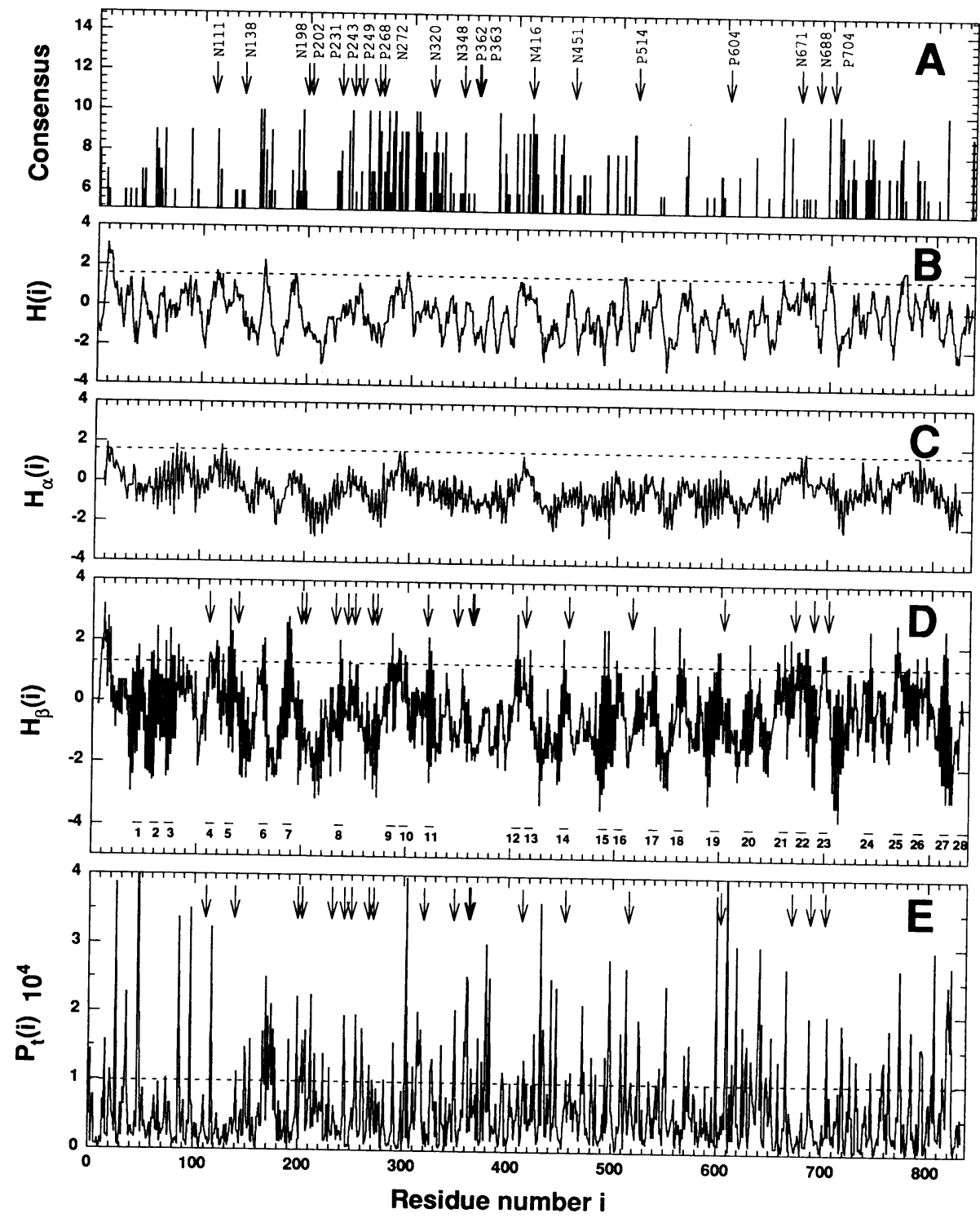

FIG. 7. Conserved residue plot (A) and structure prediction plots (19) (B to E) for the FasD protein: hydrophobicity [H(i); B], $\alpha$-helix side hydrophobicity $\left[\mathrm{H}_{\alpha}(\mathrm{i}) ; \mathrm{C}\right], \beta$-strand side hydrophobicity $\left[\mathrm{H}_{\beta}(\mathrm{i}) ; \mathrm{D}\right], \beta$-turn potential $\left[\mathrm{P}_{\mathrm{t}}(\mathrm{i}) ; \mathrm{E}\right]$. Arrows in panels $\mathrm{D}$ and $\mathrm{E}$ and those with numbers in panel $A$ correspond to the insertion sites, identified as permissive (prefix $P$ ) or nonpermissive (prefix N); bars and numbers in panel $D$ indicate
28 proposed $\beta$-strands.

sive sites in FasD, in-frame linker insertions, including deletions and duplications of only a few codons, had to be identified by first demonstrating the expression of nontruncated FasD proteins. For this, inactive FasD products of 76 fas $D$ mutants with $A p a I$ insertions were studied by Western blot analysis and enhanced chemiluminescence by using the anti-FasD antibodies described above. Seven mutants were shown to express a product of the size corresponding to the nonmutated protein. A majority of the remaining mutants expressed no detectable product, and some of the others produced FasD proteins of lower or higher molecular mass, reflecting larger in-frame deletions or duplications. Sequence analysis of the seven nonpermissive insertions in fasD (Table 1; sites 198, 320, 348, 416, 451, 671, and 688) showed that six of them included deletions or duplications of several residues.
In summary, 11 permissive sites were identified in FasD, three being only partially permissive since they are associated with a reduced function of FasD (Table 1). The 3 partially permissive sites and 9 of the 10 identified nonpermissive sites interrupt or flank conserved residues. In contrast, six of the eight fully permissive sites are flanked by nonconserved residues on both sides. These data indicate a correlation between permissive sites and nonconserved residues and, conversely, between nonpermissive sites and conserved residues. Moreover, all permissive sites were located in or near predicted turns, whereas 5 of the 10 nonpermissive sites were identified in predicted $\beta$-amphipathic strands, suggesting a relationship between the structure and the function of FasD. The proposed nature of this relationship will be elaborated in Discussion. 
TABLE 1. Deduced primary structure, predicted secondary structure, and function of mutated FasD proteins

\begin{tabular}{|c|c|c|c|c|c|}
\hline $\begin{array}{l}\text { Site and } \\
\text { residue }^{a}\end{array}$ & Mutation $^{b}$ & Local sequence ${ }^{c}$ & Conserved ${ }^{d}$ & Prediction ${ }^{e}$ & Function $f^{f}$ \\
\hline PvuII 111 & $+4(\mathrm{I} 4+\mathrm{S} 1)$ & $\begin{array}{l}504 \text { TCA ACA GTC CCC CGG GGG ACT GAC } 515 \\
109 \text { Ser Thr Val Pro Arg Gly Thr Asp } 112\end{array}$ & + & $\beta$ & - \\
\hline StuI 138 & $+4(\mathrm{I} 4+\mathrm{S} 1)$ & $\begin{array}{l}585 \text { CCT CAG GTC CCC CGG GGG ACC TAT } 596 \\
136 \text { Pro Gly Val Pro Arg Gly Thr Tyr } 139\end{array}$ & + & - & - \\
\hline 198 & $-4(\mathrm{I} 2+\mathrm{De} 6)$ & $\begin{array}{l}768 \text { TTG AGG GCC CTG TCG } 794 \\
196 \text { Leu Arg Ala Leu Ser } 204\end{array}$ & + & $\mathrm{T}$ & - \\
\hline 202 & 0 (S3) & $\begin{array}{l}783 \text { TAC AGG GCC CAC AAT } 797 \\
201 \text { Tyr Arg Ala His Asn } 205\end{array}$ & - & $\mathrm{T}$ & +++ \\
\hline EcoRV 231 & $+4(\mathrm{I} 4)$ & $\begin{array}{l}864 \text { AAG GAT TCC CCC GGG GGA ATC GGA } 875 \\
229 \text { Lys Asp Ser Pro Gly Gly Ile Gly } 232\end{array}$ & + & $\mathrm{T}$ & + \\
\hline 243 & $0(\mathrm{~S} 2)$ & $\begin{array}{l}900 \text { GGG GAG GGC CCA ACT } 914 \\
241 \text { Gly Glu Gly Pro Thr } 245\end{array}$ & + & $\mathrm{T}$ & +++ \\
\hline 249 & $+5(\mathrm{I} 2+\mathrm{Du} 3)$ & $\begin{array}{l}915 \text { CGA GGG ATG GGG CCC CGA GGG ATG ATT } 926 \\
246 \text { Arg Gly Met Gly Pro Arg Gly Met Ile } 249\end{array}$ & - & $\mathrm{T}$ & +++ \\
\hline 268 & $+2(\mathrm{I} 2)$ & $\begin{array}{l}975 \text { ATG TT } G \text { G GC CCA AAT } 983 \\
266 \text { Met Leu Gly Pro Asn } 268\end{array}$ & + & $\mathrm{T}$ & + \\
\hline SnaBI 272 & $+4(\mathrm{I} 4+\mathrm{S} 1)$ & $\begin{array}{l}987 \text { CGT TTA CTC CCC CGG GGG AGT AGT } 998 \\
270 \text { Arg Leu Leu Pro Arg Gly Ser Ser } 273\end{array}$ & + & $\mathrm{T}$ & - \\
\hline 320 & $-2(\mathrm{I} 2+\mathrm{De} 4)$ & $\begin{array}{l}1128 \text { TAT TCG GGC CCT GTA } 1148 \\
317 \text { Tyr Ser Gly Pro Val } 323\end{array}$ & + & $\beta$ & - \\
\hline 348 & $+3(\mathrm{I} 2+\mathrm{Du} 1)$ & $\begin{array}{l}1215 \text { AAA CGC GGG GCC CGC GAG } 1223 \\
346 \text { Lys Arg Gly Ala Arg Glu } 348\end{array}$ & + & - & - \\
\hline 362 & $+5(\mathrm{I} 2+\mathrm{Du} 3)$ & $\begin{array}{l}1257 \text { CAT TAT AAT } G G G C C C \text { CAT TAT AAT AAT } 1265 \\
359 \text { His Tyr Asn Gly Pro His Tyr Asn Asn } 362\end{array}$ & - & $\mathrm{T}$ & +++ \\
\hline 362 & $+2(\mathrm{I} 2)$ & $\begin{array}{l}1260 \text { TAT AAT } G G G C C C \text { AAT } 1265 \\
360 \text { Tyr Asn Gly Pro Asn } 362\end{array}$ & - & $\mathrm{T}$ & +++ \\
\hline 363 & $+2(\mathrm{I} 2)$ & $\begin{array}{l}1260 \text { AAT AAT } G G G C C C \text { AGT } 1268 \\
361 \text { Asn Asn Gly Pro Ser } 363\end{array}$ & - & $\mathrm{T}$ & +++ \\
\hline 416 & $+2(\mathrm{I} 2)$ & $\begin{array}{l}1422 \text { GCT } G G G \text { CCC GTG } 1427 \\
415 \text { Ala Gly Pro Val } 416\end{array}$ & + & $\beta$ & - \\
\hline 451 & $-11(\mathrm{I} 2+\operatorname{Del} 3)$ & $\begin{array}{l}1257 \text { ACG GGC CCC TTT } 1301 \\
450 \text { Thr Gly Pro Phe } 464\end{array}$ & + & $\beta$ & - \\
\hline 514 & $-2(I 2+D e 4)$ & $\begin{array}{l}1713 \text { TAT TGG GCC CAT GTT } 1733 \\
512 \text { Tyr Trp Ala His Val } 518\end{array}$ & + & $\mathrm{T}$ & +++ \\
\hline 604 & $+4(\mathrm{I} 2+\mathrm{Du} 2)$ & $\begin{array}{l}1980 \text { CCG GGT TCG GGC CCG GGT TCA ATG } 2003 \\
601 \text { Pro Gly Ser Gly Pro Gly Ser Met } 604\end{array}$ & - & $\mathrm{T}$ & +++ \\
\hline 671 & $-2(I 2+\mathrm{De} 4)$ & $\begin{array}{l}2187 \text { GTG GGC CCC GCG } 2204 \\
670 \text { Val Gly Pro Ala } 675\end{array}$ & + & $\beta$ & - \\
\hline 688 & $-4(\mathrm{I} 2+\mathrm{De} 6)$ & $\begin{array}{l}2238 \text { GTT } G G G C C C \text { TCT } 2261 \\
687 \text { Val Gly Pro Ser } 694\end{array}$ & - & $\mathrm{T}$ & - \\
\hline 704 & $+2(\mathrm{I} 2)$ & $\begin{array}{l}2283 \text { ACG TCG GGC CCG ATG } 2297 \\
702 \text { Thr Ser Gly Pro Met } 704\end{array}$ & + & $\mathrm{T}$ & ++ \\
\hline \multicolumn{6}{|c|}{ 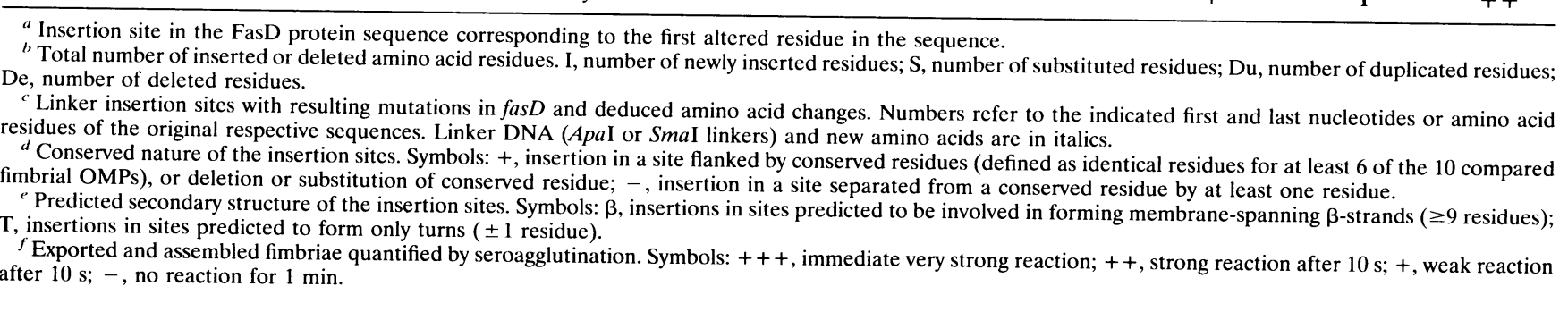 } \\
\hline
\end{tabular}




\section{DISCUSSION}

In the last few years, studies of fimbrial biogenesis have led to a better understanding of early events occurring in the periplasm. This research has focused on the interactions of fimbrial subunits with a periplasmic chaperone protein (18, 22). In contrast, little concerning the mechanisms of fimbrial subunit export at the outer membrane is known.

Here, we analyzed FasD, a 987P protein previously shown to be required for fimbrial biogenesis. By using two different techniques, we localized FasD in the outer membrane. Moreover, by developing an anti-FasD antibody probe, surface exposure of FasD on either side of the outer membrane could be demonstrated with various proteases. The primary structure of FasD, deduced from DNA sequencing, was shown to share homologous domains with a group of proteins, each of them belonging to another fimbrial gene cluster and some of them having been characterized as OMPs. Finally, we established that linkers can be inserted into certain sites of FasD without affecting the function of its product. Since mutants with FasD ${ }^{-}$ phenotypes are nonfimbriated $(48,49)$, the biological function of FasD was tested by detecting fimbriae on the bacterial surface. By screening for fimbriated linker insertion mutants, we identified mutated fas $D$ genes encoding functional proteins. Since the only known function of FasD involves fimbrial protein export, the corresponding mutation sites were designated permissive sites, implying permissiveness of fimbriation to linker insertion.

Recent studies with the Pap fimbrial system suggest that fimbrial subunits interact directly with the fimbrial OMP (11). To understand how fimbrial subunits are exported through the outer membrane, many questions remain to be answered, as, for example, the following. (i) What is the overall structure and topology of a fimbrial OMP in the outer membrane? (ii) Which domains of a fimbrial OMP interact with the membrane, and which ones interact with fimbrial subunits. (iii) By which mechanisms are fimbrial subunits translocated? Does the fimbrial OMP participate in the formation of a fimbrial subunit channel, or in a flippase complex (15), translocating subunits through the lipid bilayer? (iv) What energy drives fimbrial export through the outer membrane?

Results of membrane insertion studies, using PhoA fusions to OMPs or secreted proteins, have been used to propose minimal protein domains required for membrane targeting. For example, studies with pullunase and with siderophore and vitamin $B_{12}$ transporters have suggested that PhoA does not cross the outer membrane or that fusions to surface-exposed domains are lethal $(7,23,29,35)$. Therefore, it is tempting to propose that the amino-terminal end of FasD contains specific targeting signals and that the active FasD-PhoA fusions which were isolated with outer membranes correspond to fusions to periplasmic loops. However, this interpretation needs to be tested since it can be argued that the folding and insertion of the FasD portion of the fusion product is not the same as that of native FasD. Because of the limitations concerning the interpretation of results obtained with fusion proteins to study OMPs, we propose another approach as discussed below.

If fimbrial OMPs of different fimbrial systems effectively share similar functions as different chaperones do, this similarity may be translated to the structural level. Fimbrial chaperone proteins share $60 \%$ similar sequences considering conservative substitutions (16), whereas fimbrial OMPs share only 20 to $30 \%$ similar sequences. Nevertheless, it has been shown that proteins which have low levels of homology (approximately $20 \%$ residue identity, by using pairwise comparisons), but share similar functions, can have common core segments which vary only slightly in their geometry (root mean square deviation of the backbone atoms, $\leq 2.4 \AA[\leq 0.24 \mathrm{~nm}])$ (6). Active sites of proteins sharing similar functions can be expected to be located in common core segments. Conserved domains of fimbrial OMPs may be involved in the translocation process of fimbrial subunits through the outer membrane. As such, these domains may include a rigid frame interacting with lipids as well as flexible domains which can be envisioned to undergo a conformational change to accommodate fimbrial subunits during export. In contrast, variable domains may be involved in the specific recognition processes of the different fimbrial subunits.

In this article, we used a random in-frame linker insertion mutagenesis technique to identify permissive sites in FasD. It was proposed that, by incorporating turn-inducing residues in this protein, (i) permissive sites would be preferentially restricted to nonconserved domains or to surface-exposed domains, predicted to form $\beta$-turns and loops, and (ii) nonpermissive sites would preferentially include sites in conserved domains or membrane-spanning domains of FasD, predicted to be $\beta$-amphipathic. Therefore, nonpermissive sites could represent essential areas in any topological domain involved in exporting fimbrial subunits as well as essential conformational structures of the protein. Such structures should be conserved among the various fimbrial OMPs. Our data support this assumption since they point to 9 conserved sites among the 10 identified nonpermissive sites. This contrasts with the location of the fully permissive sites, six of eight being flanked by nonconserved residues on both sides. Since the proposed $\beta$-barrel structure of FasD is expected to be essential for structural stability in the membrane, the function of FasD should be especially sensitive to mutations in its predicted $\beta$-amphipathic membrane-spanning strands. In support of the predicted model, we found here that all 11 identified permissive sites are located at predicted turns or at the junctions of predicted $\beta$-strands and turns. Moreover, all five linker insertions which targeted predicted $\beta$-sheets were identified as nonpermissive. These encouraging findings open new perspectives for experimental testing. For example, it will now be possible to determine whether the obtained permissive linker insertion sites are, in fact, located in surface-exposed domains by introducing reporter epitopes in such sites and probing with specific antibodies (5). Moreover, the extent of the alterations which can be made at these sites without affecting the function of FasD will test the degree of permissiveness more stringently. In a preliminary experiment, we observed that a permissive linker insertion site could tolerate a reporter epitope of 11 residues, the mutated FasD remaining functional (46a).

Finally, it has been proposed that siderophore receptors undergo a conformational change to internalize their ligands $(26,28)$. However, such changes have not been demonstrated in vivo. Whether FasD undergoes conformational changes during fimbrial export may be more evident since the translocated molecules are much larger. The obtained fas $D$ mutants will be useful to study conformational flexibility of OMPs in the presence or absence of the fimbrial subunits and various fimbrial periplasmic proteins.

\section{ACKNOWLEDGMENTS}

We thank L. Bello for critically reading the manuscript.

This work was supported by U.S. Department of Agriculture grant 92-37204-7901, by a National Pork Producers Council research grant, and by a University of Pennsylvania Research Foundation grant.

\section{REFERENCES}

1. Abraham, S. N., D. L. Hasty, W. A. Simpson, and E. H. Beachey. 1983. Antiadhesive properties of a quaternary structure specific 
hybridoma antibody against type 1 fimbriae of Escherichia coli. J. Exp. Med. 158:1114-1128.

2. Achtman, M., P. A. Manning, C. Edelbluth, and P. Herrlich. 1979. Export without proteolytic processing of inner and outer membrane proteins encoded by F sex factor Tra cistrons in Escherichia coli minicells. Proc. Natl. Acad. Sci. USA 76:4837-4841.

3. Allen, B. L., G.-F. Gerlach, and S. Clegg. 1991. Nucleotide sequence and functions of $m r k$ determinants necessary for expression of type 3 fimbriae in Klebsiella pneumoniae. J. Bacteriol. 173:916-920.

4. Brinton, C. C. 1965 . The structure, function, synthesis and genetic control of bacterial pili and a molecular model for DNA and RNA transport in gram negative bacteria. Trans. N. Y. Acad. Sci. 27:1003-1054.

5. Charbit, A., J. Ronco, V. Michel, C. Werts, and M. Hofnung. 1991. Permissive sites and topology of an outer membrane protein with a reporter epitope. J. Bacteriol. 173:262-275.

6. Chlothia, C., and A. M. Lesk. 1986. The relation between the divergence of sequence and structure in proteins. EMBO J. 5:823-826.

7. Coulton, J. W., G. K. Reid, and A. Campana. 1988. Export of hybrid proteins FhuA'-'LacZ and FhuA'-'PhoA to the cell envelope of Escherichia coli K-12. J. Bacteriol. 170:2267-2275.

8. Cowan, S. W., T. Schirmer, G. Rummel, M. Steiert, R. Ghosh, R. A. Pauptit, J. N. Jansonius, and J. P. Rosenbusch. 1992. Crystal structures explain functional properties of two $E$. coli porins. Nature (London) 358:727-733.

9. de Graaf, F. K. 1990. Genetics of adhesive fimbriae of intestinal Escherichia coli. Curr. Top. Microbiol. Immunol. 151:29-53.

10. Dodd, D. C., and B. I. Eisenstein. 1984. Dependence of secretion and assembly of type 1 fimbrial subunits of Escherichia coli on normal protein export. J. Bacteriol. 159:1077-1079.

11. Dodson, K. W., F. Jacob-Dubuisson, R. T. Striker, and S. J. Hultgren. 1993. Outer-membrane PapC molecular usher discriminately recognizes periplasmic chaperone-pilus subunit complexes. Proc. Natl. Acad. Sci. USA 90:3670-3674.

12. Dower, W. J., J. F. Miller, and C. W. Ragsdale. 1988. High efficiency transformation of $E$. coli by high voltage electroporation. Nucleic Acids Res. 16:6127-6145.

13. Gong, M., and L. Makowski. 1992. Helical structure of P pili from Escherichia coli. J. Mol. Biol. 228:735-742.

14. Heffron, F., M. So, and B. J. McCarthy. 1978. In vitro mutagenesis of a circular DNA molecule by using synthetic restriction sites. Proc. Natl. Acad. Sci. USA 75:6012-6016.

15. Higgins, C. F., and M. M. Gottesman. 1992. Is the multidrug transporter a flippase? Trends Biochem. Sci. 17:18-21.

15a.Higgins, D. G., and P. M. Sharp. 1989. Fast and sensitive multiple sequence alignments on a microcomputer. Comput. Appl. Biosci. 5:151-153.

16. Holmgren, A., M. J. Kuehn, C.-I. Brändén, and S. J. Hultgren. 1992. Conserved immunoglobulin-like features in a family of periplasmic pilus chaperones in bacteria. EMBO J. 11:1617-1622.

17. Houmard, J., and G. R. Drapeau. 1972. Staphylococcal protease: a proteolytic enzyme specific for glutamoyl bonds. Proc. Natl. Acad. Sci. USA 69:3506-3509.

18. Hultgren, S. J., S. Normark, and S. N. Abraham. 1991. Chaperone-assisted assembly and molecular architecture of adhesive pili. Annu. Rev. Microbiol. 45:383-415.

19. Jähnig, F. 1989. Structure prediction for membrane proteins, p. 707-717. In G. D. Fasman (ed.), Prediction of protein structure and the principles of protein conformation. Plenum Press, New York.

20. Jalajakumari, M. B., C. J. Thomas, R. Halter, and P. A. Maning. 1989. Genes for biosynthesis and assembly of CS3 pili of CFA/II enterotoxigenic Escherichia coli: novel regulation of pilus production by bypassing an amber codon. Mol. Microbiol. 3:1685-1695.

21. Jeanteur, D. J., H. Lakey, and F. Pattus. 1991. The bacterial porin superfamily: sequence alignment and structure prediction. Mol. Microbiol. 5:2153-2164.

22. Jones, C. H., F. Jacob-Dubuison, K. Dodson, M. Kuehn, L. Slonim, R. Striker, and S. J. Hultgren. 1992. Adhesin presentation in bacteria requires molecular chaperones and ushers. Infect. Immun. 60:4445-4451.
23. Kadner, R. J. 1990. Vitamin $B_{12}$ transport in Escherichia coli: energy coupling between membranes. Mol. Microbiol. 4:20272033.

24. Karlyshev, A. V., E. E. Galyov, O. Y. Smirnov, A. P. Guzayev, V. M. Abramov, and V. P. Zav'yalov. 1992. A new gene of the $f 1$ operon of $Y$. pestis involved in the capsule biogenesis. FEBS Lett. 297:7780.

25. Kaufman, M. R., J. M. Seyer, and R. K. Taylor. 1991. Processing of TCP pilin by TcpJ typifies a common step intrinsic to a newly recognized pathway of extracellular protein secretion by gramnegative bacteria. Genes Dev. 5:1834-1846.

26. Klebba, P. E. 1993. Response from Rutz et al. Trends Microbiol. 1:7-8.

27. Klemm, P., and G. Christiansen. 1990. The fimD gene required for cell surface localization of Escherichia coli type 1 fimbriae. Mol. Gen. Genet. 220:334-338.

28. Koebnik, R., and V. Braun. 1993. Insertion derivatives containing segments of up to 16 amino acids identify surface- and periplasmexposed region of Fhu outer membrane receptor of Escherichia coli K-12. J. Bacteriol. 175:826-839.

29. Kornacker, M. G., and A. P. Pugsley. 1990. The normally periplasmic enzyme $\beta$-lactamase is specifically and efficiently translocated through the Escherichia coli outer membrane when it is fused to the cell-surface enzyme pullunase. Mol. Microbiol. 4:1101-1109.

30. Kuehn, M. J., S. Normark, and S. J. Hultgren. 1991. Immunoglobulin-like PapD chaperone caps and uncaps interactive surfaces of nascently translocated pilus subunits. Proc. Natl. Acad. Sci. USA 88:10586-10590.

31. Manoil, C., and J. Beckwith. 1985. TnphoA: a transposon probe for protein export signals. Proc. Natl. Acad. Sci. USA 82:8129-8133.

32. Miller, J. H. 1992. A short course in bacterial genetics: a laboratory manual and handbook for Escherichia coli and related bacteria. Cold Spring Harbor Laboratory, Cold Spring Harbor, N.Y.

33. Mooi, F. R., I. Claasen, D. Bakker, H. Kuipers, and F. K. de Graaf. 1986. Regulation and structure of an Escherichia coli gene coding for an outer membrane protein involved in export of K88ab fimbrial subunits. Nucleic Acids Res. 14:2443-2457.

34. Mooi, F. R., A. Wijfjes, and F. K. de Graaf. 1983. Identification and characterization of precursors in the biosynthesis of the K88ab fimbria of Escherichia coli. J. Bacteriol. 154:41-49.

35. Murphy, C. K., and P. E. Klebba. 1989. Export of FepA::PhoA fusion proteins to the outer membrane of Escherichia coli K-12. J. Bacteriol. 171:5894-5900.

36. Nakai, K., and M. Kanehisa. 1991. Expert system for predicting protein localization sites in gram-negative bacteria. Prot. Struct. Funct. Genet. 11:95-110.

37. Nikaido, H. 1992. Porins and specific channels of bacterial outer membranes. Mol. Microbiol. 6:435-442.

38. Norgren, N., M. Båga, J. M. Tennent, and S. Normark. 1987. Nucleotide sequence, regulation and functional analysis of the papC gene required for cell surface localization of Pap pili of uropathogenic Escherichia coli. Mol. Microbiol. 1:169-178.

39. Ofek, I., and N. Sharon. 1990. Adhesins as lectins: specificity and role in infections. Curr. Top. Microbiol. Immunol. 151:91-113.

40. Oliver, D. B., and J. Beckwith. 1982. Regulation of a membrane component required for protein secretion in Escherichia coli. Cell 30:311-319.

41. Parsot, C., E. Taxman, and J. J. Mekalanos. 1991. ToxR regulates the production of lipoproteins and the expression of serum resistance in Vibrio cholerae. Proc. Natl. Acad. Sci. USA 881:16411645.

42. Rioux, C. R., M. J. Friedrich, and R. J. Kadner. 1990. Genes on the 90-kilobase plasmid of Salmonella typhimurium confer lowaffinity cobalamin transport: relationship to fimbria biosynthesis genes. J. Bacteriol. 172:6217-6222.

43. Roosendaal, B., and F. K. de Graaf. 1989. The nucleotide sequence of the fanD gene encoding the large outer membrane protein involved in the biosynthesis of $\mathrm{K} 99$ fimbriae. Nucleic Acids Res. 17:1263.

44. Rosenbusch, J. P. 1990. Structural and functional properties of porin channels in E. coli outer membranes. Experientia 46:167173.

45. Sambrook, J., E. F. Fritsch, and T. Maniatis. 1989. Molecular 
cloning: a laboratory manual, 2nd ed. Cold Spring Harbor Laboratory, Cold Spring Harbor, N.Y.

46. Schatz, P. J., and J. Beckwith. 1990. Genetic analysis of protein export in Escherichia coli. Annu. Rev. Genet. 24:215-248.

46a.Schifferli, D. M. Unpublished data.

47. Schifferli, D. M., S. N. Abraham, and E. H. Beachey. 1987. Use of monoclonal antibodies to probe subunit- and polymer-specific epitopes of $987 \mathrm{P}$ fimbriae of Escherichia coli. Infect. Immun. 55:923-930.

48. Schifferli, D. M., E. H. Beachey, and R. K. Taylor. 1991. 987P fimbrial gene identification and protein characterization by $\mathrm{T} 7$ RNA polymerase induced transcription and TnphoA mutagenesis. Mol. Microbiol. 5:61-70.

49. Schifferli, D. M., E. H. Beachey, and R. K. Taylor. 1991. Genetic analysis of $987 \mathrm{P}$ adhesion and fimbriation of Escherichia coli: the fas genes link both phenotypes. J. Bacteriol. 173:1230-1240.

50. Schirmer, T., and S. W. Cowan. 1993. Prediction of membranespanning $\beta$-strands and its application to maltoporin. Protein Sci. 2:1361-1363.

51. Silhavy, T. J., M. L. Berman, and L. W. Enquist (ed.). 1984.
Experiments with gene fusions. Cold Spring Harbor Laboratory, Cold Spring Harbor, N.Y.

52. Sugimura, K., and N. Higashi. 1988. A novel outer-membraneassociated protease in Escherichia coli. J. Bacteriol. 170:36503654.

53. Tabor, S., and C. C. Richardson. 1985. A bacteriophage T7 RNA polymerase/promoter system for controlled exclusive expression of specific genes. Proc. Natl. Acad. Sci. USA 82:1074-1078.

54. Von Heijne, G. 1986. A new method for predicting signal sequence cleavage sites. Nucleic Acids Res. 14:4683-4690.

55. Weiss, M. S., and G. E. Schultz. 1992. Structure of porin refined at 1.8 Å resolution. J. Mol. Biol. 227:493-509.

56. Willems, R. J. L., H. G. J. van der Heide, and F. R. Mooi. 1992 Characterization of a Bordetella pertussis fimbrial gene cluster which is located directly downstream of the filamentous haemagglutinin gene. Mol. Microbiol. 6:2661-2671.

57. Witholt, B., M. Boekhout, M. Brock, J. Kingma, H. van Heerikhuizen, and L. de Leij. 1976. An efficient and reproducible procedure for the formation of spheroplasts from variously grown Escherichia coli. Anal. Biochem. 74:160-170. 